\title{
Randomized interventional trial comparing conjunctival autograft secured with Sutures versus fibrin glue in primary pterygium excision
}

\author{
Keerthivarman Rukmangathan", Dhivya Ramakrishnan², Vasudarini Sundararajan ${ }^{3}$, Ranjan Chandrasekaran ${ }^{4}$, \\ Ramusiddharthan Ravichandran ${ }^{5}$, Shankar Radhakrishnan ${ }^{6}$ \\ ${ }^{1}$ Dr. Keerthivarman Rukmangathan, Assistant Professor, ${ }^{2}$ Dr. Dhivya Ramakrishnan, Senior Resident, ${ }^{3}$ Dr. Vasudarini \\ Sundararajan, Professor and Head, ${ }^{1,2,3}$ All are affiliated with Department of Ophthalmology, Annapoorana Medical \\ College \& Hospital, Veerapandi, Salem, Tamil Nadu-636308, ${ }^{4}$ Dr. Ranjan Chandrasekaran, Consultant, Annai Eye \\ Hospital, Ramanathapuram, ${ }^{5}$ Dr. Ramusiddharthan Ravichandran, Consultant, Sri Ramana Maharishi Eye Hospital, 53 C, \\ Somavarakula street, Tiruvannamalai. Pin 636601, ${ }^{6}$ Dr. Shankar Radhakrishnan, Associate Professor, Department of \\ Preventive Medicine, VMKVMCH, Salem, Tamil Nadu- 636308, India.
}

Corresponding Author: Dr. Keerthivarman Rukmangathan, Assistant Professor, Department of Ophthalmology, Annapoorana Medical College \& Hospital, Veerapandi, Salem, Tamil Nadu- 636308, India. Email: dockeerthi87@gmail.com

\begin{abstract}
Background: An ideal pterygium surgery should achieve three principal goals: a low recurrence rate, absence of complications, and satisfactory cosmesis. Natural substances, such as fibrin, have significant advantage in achieving these goals. Aim: To compare the primary \& secondary outcomes following primary pterygium excision with conjunctival auto graft using fibrin glue versus sutures. Methodology: A prospective interventional study was conducted at Department of Ophthalmology, Annapoorana medical college\& Hospital, Salem, India, for a period of one year from June 2016 to May 2017. A total of 87 patients were included in the study. They were randomized into two groups. Group I received conjunctival auto graft secured with glue and Group II received conjunctival auto graft secured with suture. Postoperatively the patients were followed for a period of 6 months for measuring the primary and secondary outcomes. Results: The mean rank score for graft inflammation, and patients discomfort was less in fibrin glue group when compared to suture group during the follow-up period from $15^{\text {th }}$ to $90^{\text {th }}$ postoperative day and the difference was found to be statistically significant, whereas the mean rank for graft stability was lower in the suture group when compared to the fibrin glue group with a statistical significant difference between the two group. Conclusion: The use of fibrin glue removes the need for the tedious suturing process, the learning curve can be shortened, and better results may be more consistently achieved despite differences in surgical expertise.
\end{abstract}

Keywords: Fibro vascular, Conjunctival, Aetiology

\section{Introduction}

Pterygium is an encroachment of fibro vascular tissue from the bulbar conjunctiva onto the cornea [1]. Various mechanisms have been suggested by previous studies, including degeneration, oxidative stress, antiapoptosis, extra cellular matrix remodeling, immunelogic mechanisms, angiogenesis, viral infections, and genetic factors [2-5].

An increased incidence of pterygium is noted in the tropics in an equatorial zone between 30 degrees north and south latitudes. Though exact aetiology is not

Manuscript received: $4^{\text {th }}$ April 2018

Reviewed $14^{\text {th }}$ April 2018

Author Corrected; $20^{\text {th }}$ April 2018

Accepted for Publication: $24^{\text {th }}$ April 2018 known, risk factors include genetic predisposition, chronic environmental irritations like dust, dryness, heat and ultraviolet rays [6,7]. The prevalence of pterygium in India was reported between 8 and $15 \%$ from various studies and globally the prevalence was ranging between 2 and $30 \%$ [8,9].

Common indications for surgical excision of the pterygium include impending or manifest loss of visual acuity or persistent discomfort despite medical therapy. Visual acuity may be diminished secondary to growth within the visual axis or due to astigmatism induced by the flattening effect of the pterygium on the cornea. Other indications for surgical intervention include 


\section{Original Research Article}

ocular motility restriction, dysplastic looking lesions or for cosmetic purposes. Pterygium surgery today can be divided into four main groups: Bare sclera excision, excision with conjunctival closure / transposition, excision with antimitotic adjunctive therapy, ocular surface transplantation techniques [10].

An ideal pterygium surgery should achieve three principal goals: a low recurrence rate, absence of complications, and satisfactory cosmesis [11]. The results of pterygium surgery are compromised by recurrence of the pterygium in a significant number of cases [12].

Traditionally, during pterygium surgery the conjunctival autografts are secured in place with either absorbable or non-absorbable sutures. The sutures had led to various levels of discomfort to the patients and it was also associated with increased risk of inflammation.

Later tissue adhesives have been used for closing and apposing wound edges. Synthetic tissue adhesives, such as cyanoacrylate, induce sufficient fibrin cross-linking kinetics but its use was limited because of its direct tissue toxicity and the barrier effect [13]. Natural substances, such as fibrin, have significant advantage in terms of minimal tissue reaction. The use of fibrin glue for pterygium surgery was first described by Cohen et al in 1993 [14]. Since then various reports have been published regarding the safety and efficacy of fibrin glue in ophthalmic surgery.

As of today, very few studies were conducted in this part of India to compare the efficacy between fibrin glue and sutures for primary pterygium excision surgery with conjunctival limbal auto graft.

\section{Aim}

To compare the primary \& secondary outcomes following primary pterygium excision with conjunctival auto graft using fibrin glue versus sutures.

\section{Methodology}

Study area: Department of Ophthalmology, Annapoorana medical college \& Hospital, Salem, Study design: Prospective interventional study

Study period: one year from June 2016 to May 2017.

Sampling technique: simple random technique was followed for randomizing the subjects into two groups and purposive sampling was applied for determining the total study subjects.
Inclusion criteria: Men and women between $20-60$ years of age requiring nasal pterygium excision for the first time were included for the study.

Exclusion criteria: Patients presenting with pseudoterygium, recurrent pterygium, double headed pterygium (nasal and temporal), age group less than 20 years and more than 60 years, one eyed patient, patients with ocular surface pathology and collagen vascular disease, patients with visually significant cataract were excluded from the study.

Study procedure: The study was started after getting the clearance from the institutional ethical committee and the informed consent from the patients who had participated in the study. A total of 87 patients were included in the study. Through a computer generated random number table all the 87 patients were randomized into two groups. Group I (44 patients) received conjunctival auto graft secured with glue and Group II (43 patients) received conjunctival auto graft secured with suture.

The socio-demographic details was obtained from the patients and a complete ophthalmological examination including visual acuity assessment and refraction with Snellen's chart. Thorough examination of anterior segment was done with slit lamp biomicroscopy at each visit. Intraocular pressure was measured with noncontact tonometer before surgery \& at $2 \& 4$ weeks after surgery. Keratometry reading was obtained using Bausch \& Lomb manual keratometer preoperatively \& at $1 \mathrm{st} / 3 \mathrm{rd} / 6$ thmonth. Fundus examination was done using slit lamp biomicroscope and 90D lens.

Patients with ocular pathology other than error of refraction, with a history of previous ocular surgery or trauma, narrow occludable angles, ocular hypertension, physiologic or glaucomatous optic disc cupping, a family history of glaucoma were excluded. Anterior segment photography was also taken preoperatively and on postoperative follow up visits. If any complications were encountered during follow up, photographic documentation was done. Pterygium grading was done according to morphology grading of Donald Tan, as T1, $\mathrm{T} 2$ and T3. Grade T1(atrophic)- pterygium in which episcleral vessels underlying the body of the pterygium were unobscured and clearly distinguished, Grade T3 (fleshy)- thick pterygium in which episcleral vessels underlying the body of the pterygium are totally obscured by fibrovascular tissue - Grade T2 (intermediate) - All other pterygia that do not fall into these two categories [15]. 


\section{Original Research Article}

All cases were taken up under regional anesthesia. The pterygium was excised with Westcott scissors over the sclera and removed from the cornea with toothed forceps and crescent blade. The conjunctival donor graft site was marked on all sides with gentian violet to outline an oversized graft with an additional $1.0 \mathrm{~mm}$ of length and width relative to the dimensions of the graft bed.

The epithelial side was marked to prevent graft inversion. The free graft then was placed on top of the cornea and kept moist using sterile normal saline solution. The conjunctival graft was positioned on the cornea so that limbal edge matched the donor site.

Sutured auto grafts: The conjunctival graft was slid into position and sutured with multiple interrupted 8.0 Vicryl polyglactin sutures. The knots were not buried but cut short. A minimum of eight and maximum of 10 sutures were required.
Fibrin glued auto grafts: The scleral bed was dried and diathermy was used to cauterize any bleeding vessels. The fibrin glue was applied to the bed and the graft was slid across into position. The graft was manipulated during the first 30 seconds and then left untouched for the cure time of 3 minutes. Any excess glue was removed with a dry spear after the 3-minutes cure time and the graft was trimmed if necessary.

Post-operatively topical antibiotic-steroid drops were prescribed. Subjective sensations of pain, foreign body sensation, tearing, and discomfort were evaluated on the first postoperative day and on weeks 2 , and on $1 / 3 / 6$ months using a 5-point scale adapted from Lim-BonSiong et al [16]. The primary outcome measure was graft success and stability which was defined as presence of intact graft at six months after surgery. The secondary outcome measures are in terms of recurrence, complications and cosmetic appearance at the end of follow up.

\section{Results}

The age and gender wise distribution of the study subjects was shown in table 1. It is seen from the table that majority of the study subjects in both the groups are in the age group between 30 and 50 years and the mean age among both the suture group and the fibrin glue group were almost similar. Similarly the male and female distribution in both the groups also did not show a statistical significant difference (table 1). The pterygium grading was done based on Donald Tan system of grading and in our study subjects majority of the patients was in either grade II or grade III and no statistically significant difference was observed between the two groups with respect to grading of pterygium (table 2). The mean duration of surgery in suture group was found to be much longer (20.6 mins) than the fibrin glue group (12.2 mins) and the difference was found to be statistical significant (table 3). The various outcome measures which were measured during the follow up period was assessed by Man-whitney $U$ test, in which the outcome measures were ranked and the mean rank was compared between the two groups and it is interpreted as lower the rank better the outcome. The mean rank score for graft inflammation, and patients discomfort was less in fibrin glue group when compared to suture group during the follow-up period from $15^{\text {th }}$ to $90^{\text {th }}$ postoperative day and the difference was found to be statistically significant, whereas the mean rank for graft stability was lower in the suture group when compared to the fibrin glue group with a statistical significant difference between the two group. During the $180^{\text {th }}$ day examination no inflammation and patients discomfort was reported in both the groups whereas the graft stability score was almost similar in both the groups. Among the various complications reported donor site granuloma and suture granuloma was found to be higher in the suture group compared to the fibrin glue group and the difference was found to be statistically significant, where as the incidence of pyogenic granuloma was found to be higher in the fibrin glue group and other complications like reverse

Table-1: Age and gender wise distribution of the study subjects.

\begin{tabular}{|c|c|c|c|c|c|}
\hline \multirow{2}{*}{ Age group } & \multicolumn{2}{|c|}{ Group I (suture) $(\mathbf{n = 4 4 )}$} & \multicolumn{2}{|c|}{ Group II (fibrin glue) $(\mathbf{n = 4 3})$} & \multirow{2}{*}{ P value } \\
\cline { 2 - 5 } & Male & Female & Male & Female & \multirow{2}{*}{0.318} \\
\hline $\mathbf{2 1 - 3 0}$ & $5(21.7 \%)$ & $4(19 \%)$ & $4(20 \%)$ & $6(26 \%)$ & 0.621 \\
\hline $\mathbf{3 1 - 4 0}$ & $8(34.7 \%)$ & $6(28.5 \%)$ & $6(30 \%)$ & $7(30.4 \%)$ & 0.581 \\
\hline $\mathbf{4 1 - 5 0}$ & $9(39.1 \%)$ & $10(47.6 \%)$ & $9(45 \%)$ & $8(34.7 \%)$ & 0.319 \\
\hline $\mathbf{5 1 - 6 0}$ & $1(4.3 \%)$ & $1(4.7 \%)$ & $1(5 \%)$ & $2(8.6 \%)$ & \\
\hline Total & $23(100 \%)$ & $21(100 \%)$ & $20(100 \%)$ & $23(100 \%)$ & $0.486^{*}$ \\
\hline Mean \pm SD & $44.5 \pm 6.4$ & $42.6 \pm 6.8$ & $41.4 \pm 5.2$ & $43.5 \pm 5.8$ & \\
\hline
\end{tabular}

$\mathrm{P}$ value derived by chi-square test

* P value derived by student $\mathrm{T}$ test. 


\section{Original Research Article}

graft had occurred only in two patients in the fibrin glue group and all these complications had occurred between $15^{\text {th }}$ and $30^{\text {th }}$ day of the post-operative period. Among the patients in the suture group 3 patients reported with recurrence during the $180^{\text {th }}$ day of follow-up and none of the patients in the fibrin glue group had recurrence and the difference was found to be statistically significant.

Table-2: Distribution of the study subjects based on the grading of pterygium.

\begin{tabular}{|c|c|c|c|}
\hline Grading & Group I (suture) $(\mathbf{n}=\mathbf{4 4})$ & Group II (fibrin glue) $(\mathbf{n}=\mathbf{4 3})$ & \multirow{2}{*}{ P value } \\
\hline I & $4(9 \%)$ & $6(13.9 \%)$ & \\
\hline II & $24(54.5 \%)$ & $20(46.5 \%)$ & \\
\hline III & $16(36.3 \%)$ & $17(39.5 \%)$ & \\
\hline Total & $44(100 \%)$ & $43(100 \%)$ & \\
\hline
\end{tabular}

$\mathrm{P}$ value derived by chi-square test

Table-3: Comparison of mean surgery time between the two groups.

\begin{tabular}{|c|c|c|c|}
\hline $\begin{array}{c}\text { Duration of surgery in } \\
\text { minutes }\end{array}$ & $\begin{array}{c}\text { Group I (suture) }(\mathbf{n}=\mathbf{4 4}) \\
\text { Mean } \pm \text { SD }\end{array}$ & $\begin{array}{c}\text { Group II (fibrin glue) } \\
\text { (n=43) } \\
\text { Mean } \pm \text { SD }\end{array}$ & P value \\
\hline Mean & $20.67 \pm 4.89$ & $12.22 \pm 3.12$ & $<.0001$ \\
\hline Min & 10 & 8 & \\
\hline Max & 30 & 19 & \\
\hline
\end{tabular}

$\mathrm{P}$ value derived by student $\mathrm{T}$ test

Table-4: Outcome measures during the follow-up period among the two groups

\begin{tabular}{|c|c|c|c|c|c|c|c|c|c|}
\hline \multirow[t]{2}{*}{$\begin{array}{l}\text { Outcome } \\
\text { measure }\end{array}$} & \multicolumn{4}{|c|}{$\begin{array}{c}\text { Group I } \\
\text { (suture) }(n=44)\end{array}$} & \multicolumn{4}{|c|}{$\begin{array}{c}\text { Group II } \\
\text { (fibrin glue) }(n=43)\end{array}$} & $\begin{array}{c}\mathbf{P} \\
\text { value }\end{array}$ \\
\hline & $\begin{array}{l}15^{\text {th }} \\
\text { day } \\
\text { (mean } \\
\text { rank) }\end{array}$ & $\begin{array}{c}30^{\text {th }} \\
\text { day } \\
\text { (mean } \\
\text { rank) }\end{array}$ & $\begin{array}{l}90^{\text {th }} \\
\text { day } \\
\text { (mean } \\
\text { rank) }\end{array}$ & $\begin{array}{c}180^{\text {th }} \text { day } \\
\text { (mean rank) }\end{array}$ & $\begin{array}{c}15^{\text {th }} \\
\text { day } \\
\text { (mean } \\
\text { rank) }\end{array}$ & $\begin{array}{l}3^{\text {th }} \\
\text { day } \\
\text { (mean } \\
\text { rank) }\end{array}$ & $\begin{array}{c}90^{\text {th }} \\
\text { day } \\
\text { (mean } \\
\text { rank) }\end{array}$ & $\begin{array}{c}180^{\text {th }} \text { day } \\
\text { (mean rank) }\end{array}$ & \\
\hline $\begin{array}{c}\text { Graft } \\
\text { inflammation }\end{array}$ & 31.54 & 28.2 & 24.89 & $\begin{array}{c}\text { No } \\
\text { inflammation } \\
\text { reported }\end{array}$ & 18.41 & 21 & 24 & $\begin{array}{c}\text { No } \\
\text { inflammation } \\
\text { reported }\end{array}$ & $<.0001$ \\
\hline $\begin{array}{c}\text { Graft } \\
\text { stability }\end{array}$ & 24.13 & 22.5 & 23.5 & 24 & 26.67 & 27.04 & 25.28 & 24.89 & $<.001$ \\
\hline $\begin{array}{c}\text { Patients } \\
\text { discomfort }\end{array}$ & 30.80 & 27.26 & 25.28 & $\begin{array}{c}\text { No } \\
\text { discomfort }\end{array}$ & 19.28 & 22.23 & 23.5 & $\begin{array}{c}\text { No } \\
\text { discomfort }\end{array}$ & $<.001$ \\
\hline
\end{tabular}

$P$ value derived by applying Man-Whitney $U$ test

Table-5: Incidence of the various complications occurred during the follow up period between the two groups

\begin{tabular}{|c|c|c|c|}
\hline Complication & Group I (suture) $(\mathbf{n = 4 4 )}$ & Group II (fibrin glue) $(\mathbf{n = 4 3})$ & P value \\
\hline Donor site granuloma & $5(11.3 \%)$ & 0 & $<.001$ \\
\hline Pyogenic granuloma & 0 & $3(6.9 \%)$ & $<.01$ \\
\hline Suture granuloma & $8(18.1 \%)$ & 0 & $<.001$ \\
\hline Reverse graft & 0 & $2(4.6 \%)$ & 0.071 \\
\hline $\begin{array}{c}\text { Sub-conjuctival } \\
\text { hemorrhage }\end{array}$ & $1(2.2 \%)$ & $2(4.6 \%)$ & 0.362 \\
\hline Recurrence & $3(6.8 \%)$ & 0 & $<.001$ \\
\hline
\end{tabular}

$\mathrm{P}$ value derived by chi-square test 


\section{Discussions}

The present study which was conducted on 87 patients had proved that using fibrin glue shortens the duration of surgery time and also the discomfort in patients during the post-operative period. The recurrence rate was also found to be lesser in the fibrin glue group than that of patients who had sutures for the treatment of pterygium. Koranyi et al published the first randomized trial that compared pterygium surgery with sutures to surgery with tissue glue (Tisseel Duo Quick).

Their study was only slightly smaller than this one (43 patients) and, as in this study they showed a significant reduction in surgical time in their glue group of $9.7 \mathrm{~min}$ versus 18.5 min with 7-0 Vicryl [17]. They also showed a significant reduction in average pain for all days in the first week.

There were no significant differences in outcomes at the end of the 6-month follow-up period. Uy et al published a small randomized trial of fibrin glue (Beriplast P) with 11 eyes per group in 2005 [18].

They described similar results to our study; reduced operating time and fewer postoperative symptoms. Bahar et al published a report in 2006 with 65 patients and confirmed decreased surgical time and reduced symptoms and signs out to day 10 [19]. Fibrin glue (Quixil) was used and compared with 8.0 Vicryl.

In the present study we found the graft stability is better in the suture group patients than that of the patients in the fibrin glue group and the similar results was also proven by Vichare et al in their study showed a (16\%) retraction rate with tissue glue compared to $(10 \%)$ with sutures and in another study by Milind Surayanshi reported an equal retraction in both the suture and fibrin glue group [20,21].

A slightly higher rate of graft retraction in the nonsuture group in the present study can be due to movement of the graft, due to lid movement causing displacement of the graft and tissue glue is vulnerable to mechanical forces hence the importance of postoperative care must be explained to the patients in detail.

The present study had shown that the recurrence rate was higher among the suture group than the fibrin glue group and it was substantiated by a study done by B M Oswald et al where they had reported the recurrence rate of $5.3 \%$ for fibrin glue versus $13.5 \%$ for sutures and he also quoted that the lesser incidence of recurrence in the fibrin glue group might be due to the immediate adherence of the graft and lack of post operative inflammation in glue technique which would inhibit fibroblast in-growth and reduce the recurrence [22]. Another study done by Alok Sati etal in their study of 90 eyes comparing the efficacy of three surgical methods of conjunctival autograft fixation in the treatment of pterygium using sutures, tissue glue and autologous blood had found a similar recurrence rate amongst the three groups $(\mathrm{p}=0.585)$ [23].

The added cost of the Tisseel glue compared with the cost of Vicryl sutures does not make it economically justifiable. These costs have been approximated to one glue cost equals four to five sutures cost in other countries. Koranyi suggests using the same Tisseel syringe on six to seven patients on the same operating list and using sterile techniques without the risk of cross-contamination would possibly reduce the cost or in par with the cost of the sutures [17].

\section{Conclusion}

To conclude both glued and sutured conjunctival auto grafting procedures are safe and effective methods for pterygium surgery. Given the savings in operating time and using one glue kit for six to seven patients, we believe that fibrin glue technique may be cost-effective overall. In addition, the decreased postoperative patient discomfort with fibrin glue is a significant advantage for up to 15 days.

The use of fibrin glue removes the need for the tedious suturing process, the learning curve can be shortened, and better results may be more consistently achieved despite differences in surgical expertise. A disadvantage is the possibility of complications like subconjunctival hemorrhage / granuloma / reduced graft stability in early postoperative period, but with good surgical technique and patient selection these could be minimized.

Current study adding to the existing knowledge: Usage of fibrin glue for pterygium surgeries will add on to the more stability of the autograft rather than suturing.

\section{Contributions by the authors}

- Keerthivarman Rukmangathan (corresponding author) - designing the entire study 


\section{Original Research Article}

- Dhivya Ramakrishnan, Vasudarini Sundararajan, Ranjan Chandrasekaran- Operating surgeons

- Ramusiddharthan Ravichandran- Preparing the manuscript

- Shankar Radhakrishnan-statistical analysis.

Funding: Nil, Conflict of interest: Nil

Permission from IRB: Yes

\section{References}

1. Coroneo MT, Di Girolamo N, Wakefield D. The pathogenesis of pterygia. Curr Opin Ophthalmol. 1999 Aug; 10 (4):282-8.

2. Di Girolamo N, Chui J, Coroneo MT, Wakefield D. Pathogenesis of pterygia: role of cytokines, growth factors, and matrix metalloproteinases. Prog Retin Eye Res. 2004 Mar;23(2):195-228.

3. Dushku N, Reid TW. Immunohistochemical evidence that human pterygia originate from an invasion of vimentin-expressing altered limbal epithelial basal cells. Curr Eye Res. 1994 Jul;13(7):473-81.

4. Tsai YY, Cheng YW, Lee H, Tsai FJ, Tseng SH, Lin CL, Chang KC. Oxidative DNA damage in pterygium. Mol Vis. 2005 Jan 25;11:71-5.

5. Tan DT, Tang WY, Liu YP, Goh HS, Smith DR. Apoptosis and apoptosis related gene expression in normal conjunctiva and pterygium. Br J Ophthalmol. 2000 Feb; 84(2):212-6.

6. Nemesure B, Wu SY, Hennis A, Leske MC; Barbados Eye Studies Group. Nine-year incidence and risk factors for pterygium in the barbados eye studies. Ophthalmology. 2008 Dec; 115(12): 2153-8. doi: 10. 1016/j.ophtha.2008.08.003. Epub 2008 Oct 18.

7. Allen B.D.S., Short P., Crawford G.J. Pinguecula and pterygia. Surv Ophthalmol. 1988;32:41-49.

8. Ang M, Li X, Wong W, Zheng Y, Chua D, Rahman A, Saw SM, Tan DT, Wong TY. Prevalence of and racial differences in pterygium: a multiethnic population study in Asians. Ophthalmology. 2012 Aug;119(8): 1509-15. doi: 10.1016/j.ophtha.2012.02. 009. Epub 2012 Apr 10.

9. Landers J, Henderson T, Craig J. Prevalence of pterygium in indigenous Australians within central Australia: the Central Australian Ocular Health Study.
Clin Experiment Ophthalmol.2011. 39 (7): 604-606. doi: 10.1111/j.1442-9071.2011.02532.x. Epub 2011 Apr 27.

10. Hirst LW. The treatment of pterygium. Surv Ophthalmol. 2003;48 (2):145-180. DOI: https://doi.org/ 10.1016/S0039-6257(02)00463-0.

11. MacKenzie FD, Hirst LW, Kynaston B, Bain C. Recurrence rate and complications after beta irradiation for pterygia. Ophthalmology. 1991 Dec; 98 (12):177680; discussion 1781.

12. Youngson RM. Recurrence of pterygium after excision. Br J Ophthalmol. 1972 Feb; 56 (2):120-5.

13. Ordman LJ, Gillman T. Studies in the healing of cutaneous wounds. I. The healing of incisions through the skin of pigs. Arch Surg. 1966Dec; 93(6): 857- 82.

14. Cohen RA, McDonald MB. Fixation of conjunctival autografts with an organic tissue adhesive. Arch Ophthalmol. 1993 Sep;111(9):1167-8.

15. Tan DT, Chee SP, Dear KB, Lim AS. Effect of pterygium morphology on pterygium recurrence in a controlled trial comparing conjunctival autografting with bare sclera excision. Arch Ophthalmol 1997; 115 (10): 1235-40.

16. Lim-Bon-Siong R, Valluri S, Gordon ME, Pepose JS. Efficacy and safety of the ProTek (Vifilcon A) therapeutic soft contact lens after photorefractive keratectomy. Am J Ophthalmol. 1998 Feb; 125 (2): 169-76.

17. Koranyi G, Seregard S, Kopp ED. Cut and paste: a no suture, small incision approach to pterygium surgery. Br J Ophthalmol. 2004 Jul;88(7):911-4.

18. Uy HS, Reyes JM, Flores JD, Lim-Bon-Siong R. Comparison of fibrin glue and sutures for attaching conjunctival autografts after pterygium excision. Ophthalmology. 2005 Apr;112(4):667-71.

19. Bahar I, Weinberger D, Gaton DD, Avisar R. Fibrin glue versus vicryl sutures for primary conjunctival closure in pterygium surgery: long-term results. Curr Eye Res 2007; 32 (5): 399-405. DOI: 10.1080/ 027136 80701294723

20. Nitin Vichare, Lt Col, Tarun Choudhary, Surg Cdr, and Priyanka Arora. A comparison between fibrin 
sealant and sutures for attaching conjunctival autograft after pterygium excision. Med J Armed Forces India. 2013; 69 (2): 151-155. doi: 10.1016/j. mjafi. 2012. 09. 002.

21. Milind Suryawanshi, Rohini Suryawanshi. Pterygium Surgery: Free Conjunctival Graft with Fibrin Glue versus Sliding Conjunctival Graft with Sutures: A Comparative Study. Sch. J. App. Med. Sci., 2015; 3 (1D): 276-280. DOI: 10.18231/2395-1451. 2016.0016
22. B.M. Oswald, LM July, C. Gury, M. Disdet, V. Leclue. Fatal intra operative anaphylaxis related to aprotinin after local application of fibrin glue. Anaesthesiology.2003;99: pp. 762-763.

23. Alok Sati, Sandeep Shankar, Ashok Jha et al. Comparison of efficacy of three surgical methods of conjunctival autograft fixation in the treatment of pterygium. Int Ophthalmol. 2014;34(6):1233-1239. doi: 10. 1007/s10792-014-0013-y. Epub 2014 Nov 6.

\section{How to cite this article?}

Keerthivarman Rukmangathan, Dhivya Ramakrishnan, Vasudarini Sundararajan, Ranjan Chandrasekaran, Ramusiddharthan Ravichandran, Shankar Radhakrishnan. Randomized interventional trial comparing conjunctival autograft secured with Sutures versus fibrin glue in primary pterygium excision. Trop J Ophthalmol Otolaryngol.2018;3 (2):1-7. doi: 10.17511/jooo.2018.i02.01 